American Journal of Agricultural and Biological Sciences 5 (3): 331-341, 2010

ISSN 1557-4989

(C) 2010 Science Publications

\title{
Effect of Different Sanitizers on Microbial, Sensory and Nutritional Quality of Fresh-Cut Jalapeno Peppers
}

\author{
${ }^{1}$ Saul Ruiz-Cruz, ${ }^{2}$ Emilio Alvarez-Parrilla, ${ }^{2}$ Laura A. de la Rosa, \\ ${ }^{2}$ Alejandra I. Martinez-Gonzalez, ${ }^{3}$ Jose de Jesus Ornelas-Paz, \\ ${ }^{4}$ Ana Maria Mendoza-Wilson and ${ }^{4}$ Gustavo A. Gonzalez-Aguilar \\ ${ }^{1}$ Department Biotechnology and Food Science, Sonora Institute of Technology, \\ 85000 Ciudad Obregon, Sonora, México \\ ${ }^{2}$ Department Chemical-Biological Sciences, Universidad Autónoma de Ciudad Juárez, \\ Institute of Biomedical Sciences, 32310 Ciudad Juárez, Chihuahua, México \\ ${ }^{3}$ Department Physiology and Food Technology of the Template Zone, \\ Center of Research in Food and Development, AC (CIAD), 31570 Cuauhtémoc, Chihuahua, Mexico \\ ${ }^{4}$ Department Technology of Foods of Vegetable Products, AC (CIAD), \\ 83000 Hermosillo, Sonora, México
}

\begin{abstract}
Problem statement: Sanitation is a critical step to insure safety of fresh-cut produce. The inadequacies of chlorine, currently used as a sanitizer, have stimulated interest in finding safer, more effective sanitizers, however little is known on the impact of these novel sanitizers on sensory and nutrimental quality of the treated products. Approach: The effect of four sanitizers: Sodium hypochlorite (OCl), Peroxiacetic Acid (PA), Acidified Sodium Chlorite (ASC) and carvacrol on microbiological, sensorial and nutritional quality (total phenols, vitamin $\mathrm{C}$ and antioxidant capacity) of fresh-cut jalapeno peppers stored at $5^{\circ} \mathrm{C}$ during 27 days was evaluated. Results: All sanitizers (except carvacrol) maintained microbiological and overall quality of jalapeno peppers during 27 days. ASC (500 and $250 \mathrm{mg} \mathrm{L}^{-1}$ ) maintained the best microbiological and sensorial properties at the end of the storage period. Carvacrol, active ingredient of oregano essential oil, maintained shelf life for only 17 days. At the end of the storage period, all treatments showed a decrease of $12-43 \%$ respect to the initial vitamin $\mathrm{C}$ values. Total phenols and antioxidant capacity decreased in a lesser degree. None of the treatments except ACS $500 \mathrm{mg} \mathrm{L}^{-1}$, induced higher losses of vitamin C, total phenols or antioxidant capacity compared to control. Conclusion: Our results showed that all sanitizers were capable of controlling microbial growth without inducing major loss of antioxidant capacity and photochemical. Carvacrol was the only sanitizer that reduced sensory acceptability of fresh-cut jalapeno peppers, however carvacrol treated samples retained the highest levels of photochemical and antioxidant capacity. ASC was the most effective sanitizer even though it was used at concentrations lower that those currently approved by the FDA.
\end{abstract}

Key words: Jalapeno pepper, sanitizers, antioxidant capacity, microbial growth, overall quality

\section{INTRODUCTION}

Hot peppers are very important in the Mexican diet; together with corn "tortillas" and beans they are part of the basic diet of a large percentage of the population. Hot and sweet peppers (Capsicum annuиm L.) are good sources of vitamins A, C and antioxidants (Chuah et al., 2008; Deepa et al., 2007; Materska and Perucka, 2005; Topuz and Ozdemir, 2007). Concentration of these compounds depends on cultivar, maturity, growing conditions and postharvest manipulation. Considering their high concentration of bioactive compounds and widespread use among the Mexican population, there has been an interest in producing fresh-cut peppers (Gonzalez-Aguilar et al., 2008a; Raffo et al., 2008).

Studies have shown that fresh-cut products are particularly susceptible to microbial growth owing to the removal of plant protective tissues and the release of cellular fluids from cutting (Heard, 2002), which

Corresponding Author: Saul Ruiz-Cruz, Department Biotechnology and Food Sciences, Sonora Institute of Technology, 85000 Ciudad Obregon, Sonora, México Tel: +55 (644) 4109000/Ext 2106 Fax: +55 (644) 4100910 
results in shelf life reduction and food-borne illnesses Given that fresh-cut products are marketed as prewashed and ready to eat and not subject to further microbial killing steps, the development and proper application of sanitizing agents to remove microorganisms and control pathogen crosscontamination effectively is critical to ensure the quality and safety of fresh-cut produce (Ruiz-Cruz et al., 2006a). Fresh-cut produce deteriorates faster than intact product; this deterioration affects not only sensorial and microbiological quality, but also nutrimental quality, since concentration of bioactive compounds decreases as a consequence of deterioration.

Chlorine (sodium hypochlorite, $\mathrm{OCl}$ ) has been widely used as a sanitizer during produce washing (Sapers, 2003). However, numerous studies have shown that chlorine used at concentrations permitted by the FDA lacks efficacy in removing human pathogens and spoilage microorganisms (Zhang and Farber, 1996). Additionally, chlorine may react with organic matter in water to form carcinogenic products (Parish et al., 2003). The inadequacies of chlorine as a sanitizer have stimulated interest in finding safer, more effective sanitizers (Sapers, 2001; 2003). Alternatives to chlorine, such as chlorine dioxide, ozone, peroxyacetic acid, acidified sodium chlorite and some essential oils have been already proposed (Beuchat, 1998). Acidified sodium chlorite has shown strong antimicrobial activity against E. coli O157:H7, Salmonella, Listeria monocytogenes and spoilage microorganisms on fresh-cut produce (Gonzalez-Aguilar et al., 2004; Ruiz-Cruz et al., 2007). Peroxyacetic acid has also been shown to be effective against spoilage and pathogenic microorganisms (Rodgers et al., 2004). Among essential oils, oregano essential oil and its active component carvacrol have been widely recognized for its antimicrobial properties (Lambert et al., 2001; Zhou et al., 2007), however they are also known to produce undesirable flavors in treated produce (Rojas-Grau et al., 2009).

Several approaches have been addressed in order to minimize deterioration of fresh-cut peppers, such as modified atmosphere packaging, sanitization and cold storage (Raffo et al., 2008; Conesa et al., 2007). However, little information of the effect of these conservation techniques on the nutrimental and sensory quality of fresh-cut peppers has been published. For this reason, the aim of the present study was to evaluate the effect of different sanitizer agents on the microbial reduction of fresh-cut Jalapeno Peppers during cold storage and their impact on the sensory quality, antioxidant capacity, total phenols and vitamin C concentration.

\section{MATERIALS AND METHODS}

Fresh-cut peppers preparation: Fresh jalapeno peppers fruits (Capsicum annum $\mathrm{cv}$. L) cultivated in the area of Delicias, Chihuahua, Mexico and purchased at a local wholesale market in the same city were used for this study. Fruit were sorted to eliminate damaged, poor quality fruit. Jalapeno peppers were washed with tap water to remove residual soil and cut manually into 1 $\mathrm{cm}$ width longitudinal strips. Cut peppers were divided into individual $1.6 \mathrm{~kg}$ portions contained in nylon mesh bags and washed in the selected sanitizer solutions as described below.

Sanitization procedure: Jalapeno strips were submerged in 1:10 ratio (wt/v) solutions containing (i) $200 \mathrm{~mL} \mathrm{~L}^{-1}$ sodium hypochlorite $(\mathrm{OCl})$ (Cloralex, NL, Mexico, $6 \% \mathrm{NaOCl}$ )and $\mathrm{pH}$ was adjusted to 6.5 with $\mathrm{HCl}$; (ii) peroxiacetic acid (PA, $80 \mathrm{~mL} \mathrm{~L}^{-1}$, Ecolab, St. Paul, Minn., USA.); (iii) acidified sodium chlorite (ASC, 250 and $500 \mathrm{mg} \mathrm{L}^{-1}$ ) by mixing 0.4 or $0.8 \mathrm{mg}$ $\mathrm{L}^{-1}$ of $\mathrm{NaClO}_{2}$ (Sigma-Aldrich, USA) with 2.5 and $5 \mathrm{~g}$ $\mathrm{L}^{-1}$ of citric acid (Sigma-Aldrich, USA), respectively; or iv) 1 or $2.5 \mathrm{mM}$ of carvacrol (Sigma-Aldrich, USA). Tap water washed peppers samples were used as controls. Immersion time was $1 \mathrm{~min}$ for ASC and carvacrol treatments and $2 \mathrm{~min}$ for $\mathrm{OCl}$, AP and control. After dipping, peppers were drained for $30 \mathrm{sec}$ and spin-dried for $30 \mathrm{~s}$ to remove excess of water, using a manually operated commercial salad spinner. Samples of $200 \mathrm{~g}$ each, were packaged in polypropylene bags $(18 \times 22 \mathrm{~cm})$ with an oxygen transmission rate of 290 $\mathrm{mL}$ day ${ }^{-1} \mathrm{~m}^{-1} \mathrm{O}_{2}{ }^{-1}$ and sealed using a AIE-302 impulse sealer (American IntNl Electric, Taiwan). All samples were stored at $5^{\circ} \mathrm{C}$ for up to $27 \mathrm{~d}$ for subsequent microbiological, sensorial and nutrimental analyses at 3 day intervals.

Sensory evaluation: The overall visual quality of cut peppers was evaluated following a modified procedure of Mercado-Silva et al. (1998) by a six-member trained panel. Before the test, the panel members were trained to recognize and scale the quality attributes of cut peppers. Samples were coded with three-digit random numbers to mask the treatment identity. The acceptability was scored using a nine-point hedonic scale, where $9=$ excellent, no defects, $7=$ very good, minor defects, 5 = fair, moderate defects, $3=$ poor, major defects and $1=$ unusable. Minor defects were attributed to dryness of the surface tissue and major defects were usually due to decay. A score of 5 or below was considered to be unsalable. 
Microbial counts: Cut peppers samples (25 g) were homogenized with sterile phosphate buffers using a stomacher blender (Model 400) for $2 \mathrm{~min}$ at $230 \mathrm{rpm}$. The homogenate was serially diluted by a ten factor. For each dilution, $1 \mathrm{~mL}$ was plated on each medium according to Mexicans Official Norms (NOM). Plate count agar (Difco) incubated aerobically at $35^{\circ} \mathrm{C}$ for 24-48 $\mathrm{h}$ for total aerobic bacteria; violet red bile agar (Difco) incubated at $35^{\circ} \mathrm{C}$ for $24-26 \mathrm{~h}$ for coliforms and potato dextrose agar supplemented with $10 \%$ of tartaric acid for yeast and molds. Results are expressed as log $\mathrm{cfu}^{-1}$ of fresh-cut jalapeno pepper.

Total phenols content: Jalapeno extracts were obtained according to the methodology proposed by Khkonen et al. (1999). Briefly, $0.1 \mathrm{~g}$ of powdered dried jalapeno was weighted into a test tube. $5 \mathrm{~mL}$ of $80 \%$ methanolic solution was added, stirred and sonicated $15 \mathrm{~min}$ in the dark. Then the tube was centrifuged $(3000 \mathrm{~g}$ ) for $10 \mathrm{~min}$ and the supernatant was collected. Extraction was repeated and total volume was taken to $10 \mathrm{~mL}$. Total phenols were determined as previously reported by Alvarez-Parrilla et al. (2007), with the Folin-Ciocalteu reagent, using Gallic acid in methanol (80\%) as standard. $50 \mu \mathrm{L}$ of extract (or standard) was mixed with $250 \mu \mathrm{L}$ of Folin-Ciocalteu reagent $(1: 10$ dilution with water) in a 96 well microplate and incubated $2 \mathrm{~min}$ at room temperature. $200 \mu \mathrm{L}$ of $\mathrm{Na}_{2} \mathrm{CO}_{3}\left(75 \mathrm{mg} \mathrm{L}^{-1}\right)$ were added and incubated during $15 \mathrm{~min}$ at $50^{\circ} \mathrm{C}$. After cooling to room temperature the absorbance at $760 \mathrm{~nm}$ was measured with a BioRad BenchmarkPlus microplate reader (BioRad Mexico, Mexico City, Mexico). Results are expressed as mg Gallic Acid Equivalent (GAE) per 100 g FW.

Ascorbic acid content: AA was determined as previously described by Gonzalez et al. (2004) $2 \mathrm{~g}$ of fresh-cut Jalapeno peppers were homogenized with $15 \mathrm{~mL}$ of metaphosphoric acid $(4 \%, \mathrm{wt} / \mathrm{v})$. The mixture was centrifuged $(3000 \mathrm{rpm})$ and the aqueous extract filtered throughout $0.45 \mu \mathrm{m}$ pore size nylon membrane (Millipore Corp., Bedford, MA). Filtered extracts were manually injected $(20 \mu \mathrm{L})$ into a Varian ProStar HPLC system (Varian Inc., Walnut Creek, CA) equipped with UV-Vis detector and fitted to a Microsorb-MV C18 reversed-phase column $(4.6 \times 250 \mathrm{~nm})$ (Varian Inc., Walnut Creek, CA). 0.2 $\mathrm{M} \mathrm{KH}_{2} \mathrm{PO}_{4}$ (adjusted at pH 2.4 with phosphoric acid) was used as mobile phase, at a 1 $\mathrm{mL} \min ^{-1}$ flow rate. Ascorbic acid was monitored at $254 \mathrm{~nm}$. Results are expressed as mg AA per100 g FW.

Antioxidant capacity: The antioxidant capacity of the different jalapeno samples was determined by both
Ferric Reducing/Antioxidant Power assay (FRAP) and DPPH radical-scavenging assay. FRAP was performed as previously described by Alvarez-Parrilla et al. (2007) FRAP reagent was daily prepared and kept at $37^{\circ} \mathrm{C}$, by mixing $0.3 \mathrm{M}$ acetate buffer, $\mathrm{pH} 3.6$ with $10 \mathrm{mM}$ TPTZ solution in $40 \mathrm{mM} \mathrm{HCl}$ plus $20 \mathrm{mM} \mathrm{FeCl} 3 \cdot 6 \mathrm{H} 2 \mathrm{O}$, at a 10:1:1 ratio. Measuring solutions were prepared in a 96 well microplate, by mixing $180 \mu \mathrm{L}$ of FRAP reagent with $24 \mu \mathrm{L}$ of diluted jalapeno extract (1:3), distilled water or $\mathrm{FeSO}_{4} \cdot 7 \mathrm{H}_{2} \mathrm{O}$ stock solutions. All measurements were carried out at $37^{\circ} \mathrm{C}$. Absorbance was measured at $595 \mathrm{~nm}$, every $30 \mathrm{~s}$, during $60 \mathrm{~min}$, using a Biorad microplate reader. Values of antioxidant capacity are reported as $\mu \mathrm{mol} \mathrm{Fe} \mathrm{F}^{2+}$ per $100 \mathrm{~g} \mathrm{FW}$.

DPPH radical-scavenging assay was performed according to Wojdylo et al. (2007), with slight modifications. $5 \mu \mathrm{L}$ of jalapeno extract (or Trolox standard solution) were mixed with $195 \mu \mathrm{L}$ of $60 \mu \mathrm{M}$ DPPH (1,1-Diphenyl-2-picrylhydrazil radical, Sigma Aldrich) in a 96 well microplate, at room temperature. Absorbance was measured at $517 \mathrm{~nm}$, every $60 \mathrm{sec}$, during $60 \mathrm{~min}$, using a Biorad microplate reader. DPPH values were determined at $30 \mathrm{~min}$ and are reported as $\mu \mathrm{mol}$ Trolox Equivalents (TE) per $100 \mathrm{~g} \mathrm{FW}$.

Statistical analysis: Experiments were repeated twice, each with three replications. Results of the two experiments were combined and values represent the mean \pm SD of six replicates. ANOVA and DMS analyses were performed in order to determine differences between sanitizer treatment and storage period (t-test), using the commercial software SPSS 13.0.

\section{RESULTS}

Sensory evaluation: Overall visual quality for all treated fresh-cut Jalapeno Peppers decreased continuously when stored at $5^{\circ} \mathrm{C}$ (Fig. 1). Water loss was the most important detrimental factor that affected fresh-cut jalapeno peppers quality. No statistical difference between control and PA treated jalapeno peppers were observed during the whole experiment. Shelf-life for these samples was 20-22 days. Peppers treated with $\mathrm{OCl}$ and both ASC concentrations showed the highest overall quality at the end of the storage $\left(27\right.$ day at $5^{\circ} \mathrm{C}$ ), in contrast, Carvacrol treated samples presented the lowest scores during all the storage period. Shelf-life of Carvacrol treated fresh-cut jalapeno peppers was only 14 day at $5^{\circ} \mathrm{C}$ (overall quality score of 5). The low quality score in these treatments was mainly due to the decayed and slimy appearance of samples. 


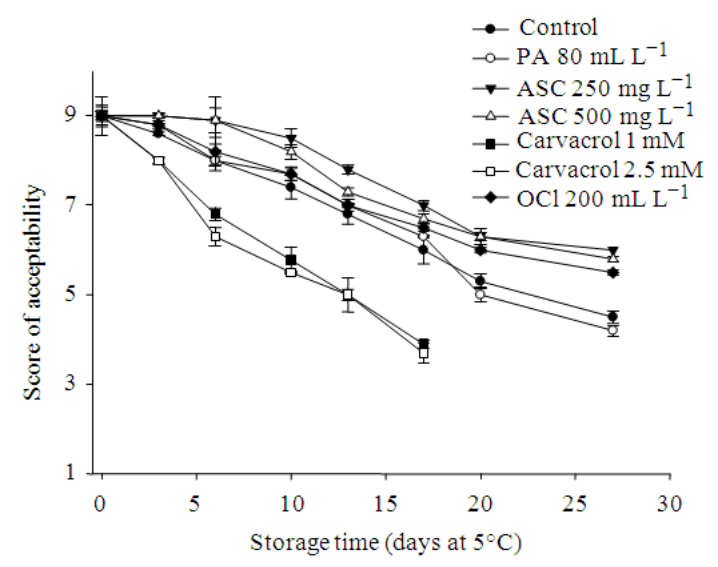

Fig. 1: Effect of carvacrol and sanitizer treatment on overall quality of packaged fresh-cut jalapeno peppers stored at $5^{\circ} \mathrm{C}$ for up to 27 days. Data points are means \pm SEM of six replicates

Microbial enumeration: Initial populations of total aerobic bacteria (Fig. 2a), total coliforms (Fig. 2b) and molds and yeasts (Fig. 2c) on unwashed peppers were 3.1, 1.4 and $1.0 \log \mathrm{cfu} \mathrm{g}^{-1}$, respectively. Treatment with all sanitizers decreased initial total aerobic bacterial counts compared with control (water-washed). PA showed the larger initial reduction. Although the aerobic bacteria grew rapidly during cold storage, at the end of the experiment (day 27), all treatments reduced total aerobic counts by $2-3 \log$ cfu g $^{-1}$ compared to control. It is important to mention that at day 17 , both carvacrol concentrations showed the best aerobic bacteria growth reduction, however, as previously described, at this day the products were not accepted by panelist. ASC treated samples (both concentrations) maintained the lowest bacterial counts throughout the storage.

All treatments (except carvacrol $1 \mathrm{mM}$ ) caused significant reductions in total coliforms count on day 0 compared with the control (Fig. 2b). This reduction was maintained throughout the storage. Reduction of 1.4$3.2 \log \mathrm{cfu} \mathrm{g} \mathrm{g}^{-1}$, were observed for the different treatments. Fresh-cut peppers washed with ASC presented the lowest microbial growth, while control peppers showed the highest coliforms growth.

The yeast and mold counts on fresh-cut peppers during 27 days of storage are shown in Fig. 2c. No microorganisms were detected during the first 3 days of storage, starting at day 6 , all treatments showed similar growth of yeasts and molds. At 17 day no statistical difference was observed between control and Carvacrol treated samples. At the end of the experiment ( 27 day), a significant decrease in yeast and mold growth was observed between all treatments (except $\mathrm{OCl}$ ) and control.

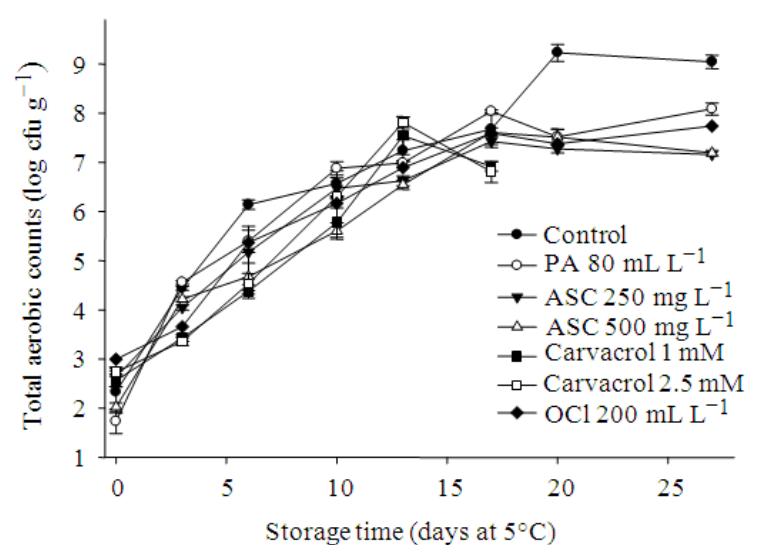

(a)

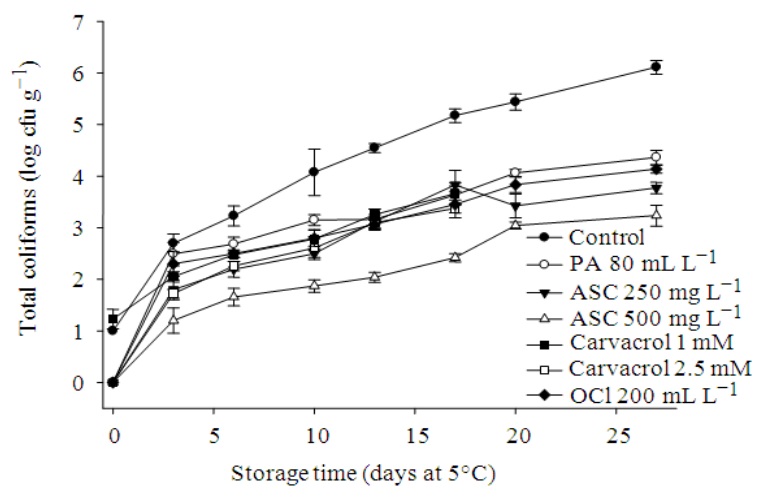

(b)

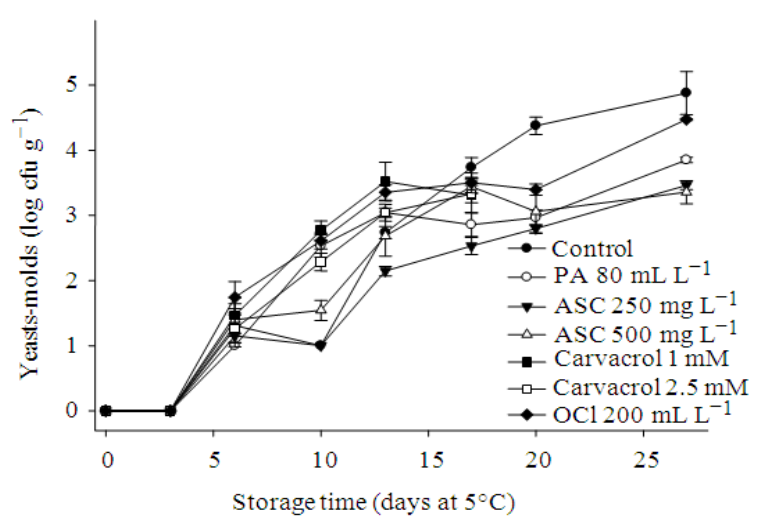

(c)

Fig. 2: Effect of carvacrol and sanitizers treatment on (a) total aerobic counts; (b) total coliforms and (c) yeasts and molds in fresh-cut jalapeno peppers stored at $5^{\circ} \mathrm{C}$ for up to 27 days. Data points are means \pm SEM of six replicates

Total phenols content: Figure 3a shows the modification of total phenol concentrations over time, for fresh-cut jalapeno peppers treated with different sanitizers. 
Am. J. Agri. \& Biol. Sci., 5 (3): 331-341, 2010

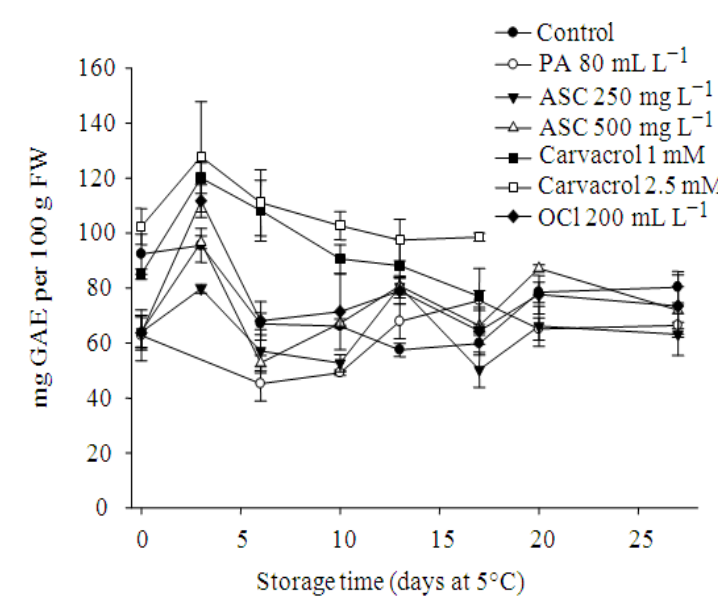

(a)

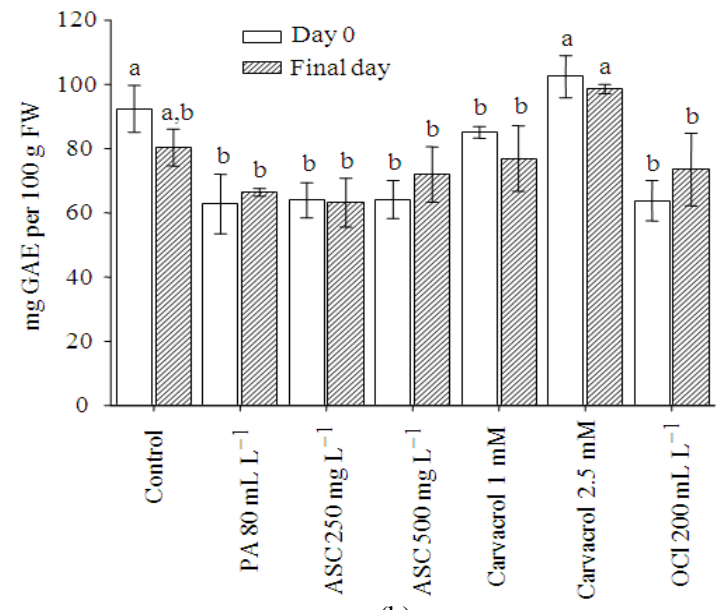

(b)

Fig. 3: Phenolic concentration of fresh-cut jalapeno peppers treated with carvacrol and sanitizers stored at $5^{\circ} \mathrm{C}$ for up to 27 days (a) Time dependent evolution of phenolic compounds (b) Initial and final concentrations. Data points are means \pm SEM of six replicates. Different letters in bars indicate statistical significant difference between treatments in either initial of final values (DMS test, $\mathrm{p}<0.05$ ). *: Means statistical difference between initial and final values ( $\mathrm{t}$-test, $\mathrm{p}<0.05$ )

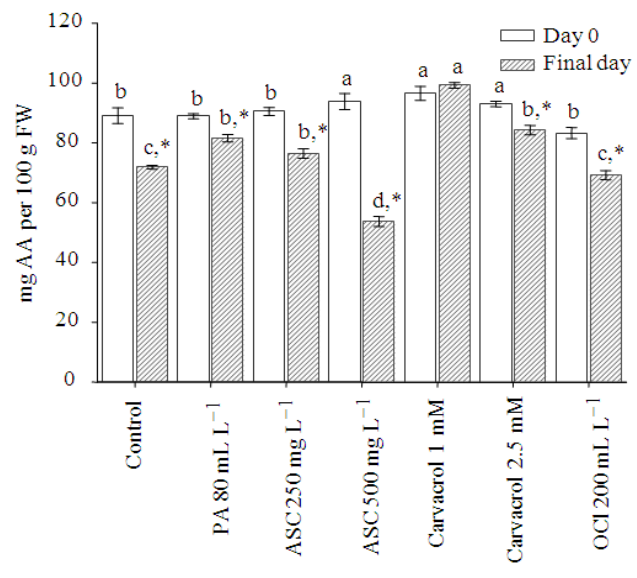

Fig. 4: Initial and final vitamin $\mathrm{C}$ concentration of fresh-cut jalapeno peppers treated with carvacrol and sanitizers stored at $5^{\circ} \mathrm{C}$ for up to 27 days. Data points are means \pm SEM of six replicates. Different letters in bars indicate statistical significant difference between treatments in either initial of final values (DMS test, $\mathrm{p}<0.05$ ). *Means statistical difference between initial and final values ( $\mathrm{t}$-test, $\mathrm{p}<0.05$ )

Initial phenolic concentrations ranged from $62.8 \mathrm{mg}$ GAE per $100 \mathrm{~g} \mathrm{FW}$ for PA treated peppers to $102.4 \mathrm{mg}$ GAE per $100 \mathrm{~g}$ FW for carvacrol $2.5 \mathrm{mM}$ treated peppers. When the initial phenolic concentrations were compared among treatments, a decrease of the initial phenolic concentration, respect to control, after the sanitization process was observed, due to a bleaching process; this reduction was not observed in carvacrol treated peppers. These results can be explained considering that carvacrol itself is a phenolic compound and consequently it is absorbed into the tissue during the sanitation process (Fig. 3b). In Fig. 3a it is possible to observe that for all treatments there is an increase on total phenols at day 3and thereafter a slight decrease is observed over time. Figure $3 \mathrm{~b}$ shows initial and final phenolic concentrations of fresh-cut jalapeno peppers treated with different sanitizers, in which a small, not significant, decrease in the phenolic concentration at the end of the shelf-life was observed. Figure $3 \mathrm{a}$ indicates that neither the sanitizers nor the storage period had any effect on the phenolic concentration of fresh-cut jalapeno peppers.

Ascorbic Acid content: Effect of sanitization on vitamin $\mathrm{C}$ concentration over the shelf-life period is presented in Fig. 4. Initial vitamin $\mathrm{C}$ values ranged from $83.2 \mathrm{mg}$ AA per $100 \mathrm{~g} \mathrm{FW}$ for $\mathrm{OCl}$ treated peppers to $96.61 \mathrm{mg} \mathrm{AA}$ per $100 \mathrm{~g} \mathrm{FW}$ for $1 \mathrm{mM}$ carvacrol treated peppers, these values were in the range of other reported for jalapeno peppers (Navarro et al., 2006; Chuah et al., 2008; Marin et al., 2004; Simonne et al., 1997; Howard et al., 2000). Carvacrol treated peppers had statistically higher vitamin $\mathrm{C}$ concentration. Vitamin C concentration decreased at the end of the storage period, except for those peppers treated with carvacrol, where the concentration remained practically unchanged, or even a slight increase was observed. 
Am. J. Agri. \& Biol. Sci., 5 (3): 331-341, 2010

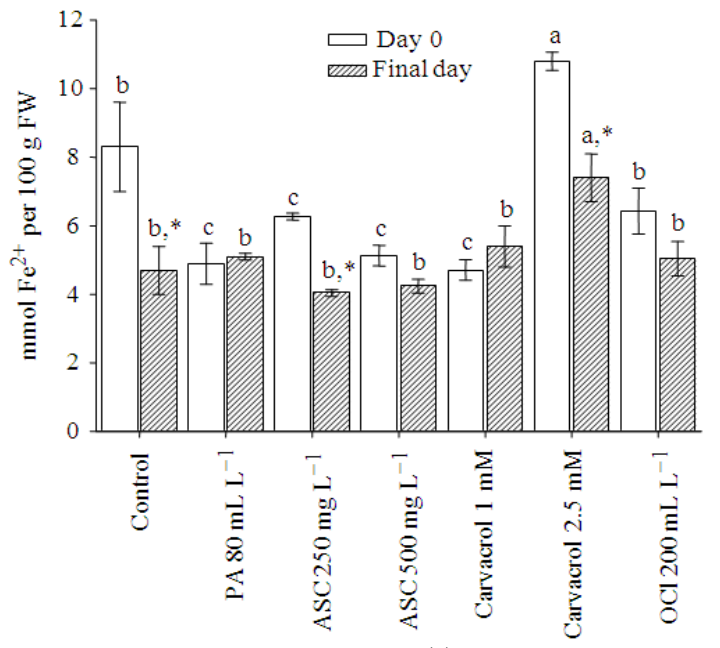

(a)

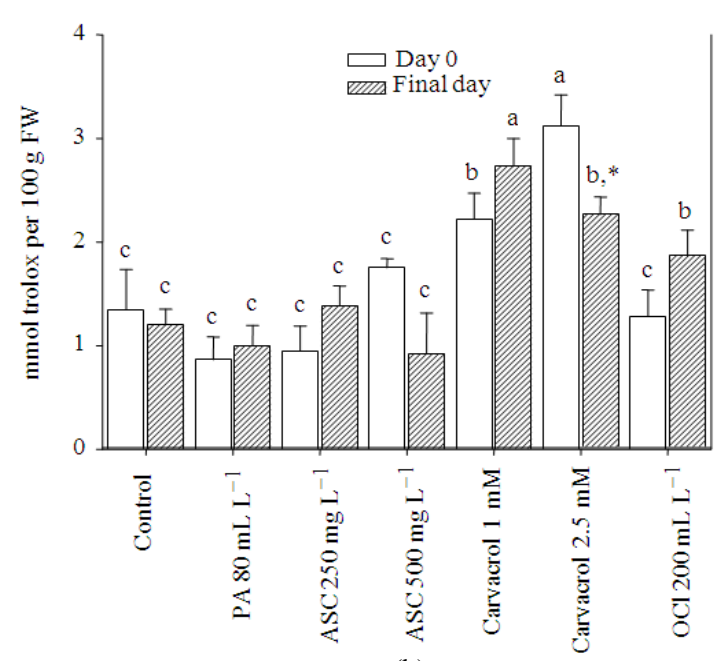

(b)

Fig. 5: Initial and final antioxidant capacity of fresh-cut jalapeno peppers treated with carvacrol and sanitizers stored at $5^{\circ} \mathrm{C}$ for up to 27 days, determined by (a) FRAP and (b) DPPH assays. Data points are means \pm SEM of six replicates. Different letters in bars indicate statistical significant difference between treatments in either initial of final values (DMS test, $\mathrm{p}<0.05)$. *: Means statistical difference between initial and final values (t-test, $\mathrm{p}<0.05)$

However, it should be considered that the storage period for these samples was only 17 days (Fig. 1). The largest vitamin $\mathrm{C}$ concentration decrease (42\%) was observed for ASC $500 \mathrm{mg} \mathrm{L}^{-1}$ treated peppers, followed by control. A $16.8 \%$ reduction was observed for the $\mathrm{OCl}$ treated jalapeno peppers. The lowest vitamin $\mathrm{C}$ loss was found in PA treated peppers (8\%). These results suggest that elaboration of fresh-cut jalapeno peppers reduces their nutrimental quality due to ascorbic acid losses; however, sanitation processes may help reduce this loss.

Antioxidant capacity: In the present study, antioxidant activity was measured by both FRAP and DPPH scavenging assays, two of the most used antioxidant capacity methods for vegetable samples. Initial FRAP antioxidant capacity value for the control was 8.32 mmol $\mathrm{Fe}^{2+}$ per $100 \mathrm{~g} \mathrm{FW}$ (Fig. 5a) and the sanitation treatment reduced the initial antioxidant capacity of all samples (values ranged from $4.71 \mathrm{mmol} \mathrm{Fe}^{2+}$ per $100 \mathrm{~g}$ FW for carvacrol $1 \mathrm{mM}$ treated peppers to $10.8 \mathrm{mmol}$ $\mathrm{Fe}^{2+}$ per $100 \mathrm{~g} \mathrm{FW}$ for carvacrol $2.5 \mathrm{mM}$ ). These results showed that during sanitation, a loss of phenolic compounds (Fig. 3b) and antioxidant capacity is observed for all treatments due to a bleaching process. The only treatment were no reduction (and even a higher FRAP values) was observed was in the carvacrol $2.5 \mathrm{mM}$ treated peppers. These results are in agreement with those observed for phenolic compounds.
When the initial and final FRAP values were compared, it is possible to observe that almost all treatments reduced the antioxidant capacity value of fresh-cut peppers during shelf-life. This reduction in the FRAP value was more evident for control $(43 \%)$ than for the other treatments. These results are similar to those obtained for vitamin $\mathrm{C}$.

Figure $5 \mathrm{~b}$ shows the initial and final DPPH values for all treated fresh-cut jalapeno peppers. Initial DPPH value for control was 1.35 mmol TE per $100 \mathrm{~g}$ FW. Once again, when the initial antioxidant capacity values of the treated peppers were compared, it is possible to observe that both carvacrol treatments increased DPPH value, however the other sanitizers had no effect on DPPH value. When initial and final values were compared (Fig. 5b), no effects were observed due to storage for all treatments except carvacrol $2.5 \mathrm{mM}$, where a significant reduction of DPPH antioxidant capacity was observed.

In order to determine which of the two compounds: The phenolic compounds or vitamin $\mathrm{C}$ was the main contributor to the antioxidant capacity of jalapeno peppers, a correlation study between the initial and final values of this two compounds with antioxidant capacity was carried out. Results are presented in Table 1. From the analysis of this Table 1, it is possible to conclude that phenolic compounds are the main contributors to antioxidant capacity in jalapeno peppers and that better correlation is observed with the FRAP method. No significant correlation was observed for vitamin C. 
Am. J. Agri. \& Biol. Sci., 5 (3): 331-341, 2010

Table 1: Correlation coefficient between phenolic compounds, vitamin $\mathrm{C}$ and antioxidant capacity assays

\begin{tabular}{lll}
\hline Correlation & $\begin{array}{l}\text { Correlation } \\
\text { coefficient }(\mathrm{R})\end{array}$ & $\begin{array}{l}\text { Pearson } \\
\text { probability }\end{array}$ \\
\hline FRAP-Folin & 0.7172 & 0.0039 \\
DPPH-Folin & 0.6743 & 0.0082 \\
FRAP-DPPH & 0.6209 & 0.0235 \\
AA-FRAP & 0.3906 & 0.1676 \\
AA-DPPH & 0.4902 & 0.0752 \\
AA + Folin-FRAP & 0.7269 & 0.0032 \\
AA C+ Folin-DPPH & 0.7587 & 0.0016 \\
\hline
\end{tabular}

A good correlation was observed when both antioxidant capacity methods were compared $(\mathrm{R}=0.62, \mathrm{p}<0.05)$. Finally, it is possible to observe that when both phenols and vitamin $\mathrm{C}$ are added, the correlation with both antioxidant capacity assays increased, indicating that in the case of jalapeno pepper, both compounds are responsible (in more or less degree) for antioxidant capacity.

\section{DISCUSSION}

Gonzalez-Aguilar et al. (2004) showed that freshcut bell pepper maintained their quality for up to 25 days at $5^{\circ} \mathrm{C}$. Therefore, this temperature was chosen in the present study, observing no visual sings of chilling injury, in fresh-cut jalapeno peppers for up to 27 days, contrasting with the study by Kang and Lee (1997) who reported that fresh-cut peppers are sensitive to chilling injury during storage at $5^{\circ} \mathrm{C}$.

Several studies have shown that sanitation is essential in preserving quality of fresh-cut fruits and vegetables, since deteriorative microorganisms are ubiquitous in fruits and, during processing, pathogenic microorganisms can infect produce (Gonzalez et al., 2004; Kang and Lee, 1997). The use of different sanitizers, such as chlorine dioxide, Peroxyacetic Acid (PA), Acidified Sodium Chlorite (ASC) and some essential oils has been proposed as an alternative to chlorine $(\mathrm{OCl})$ due to reported lack of efficacy and other disadvantages of the later (Beuchat, 1998). Although effectiveness of these sanitizers in reducing microbial growth has been demonstrated in some freshcut products, studies addressing their effect on the total quality of the products are lacking.

Initial populations of total aerobic bacteria, total coliforms and molds and yeasts on unwashed jalapeno peppers were similar to those reported for fresh-cut bell peppers (Gonzalez-Aguilar et al., 2004). Treatment of fresh-cut peppers with ASC at concentrations of 250 and $500 \mathrm{mg} \mathrm{L}^{-1}$ showed the best results in reducing growth of all microorganisms and, at the same time maintained the highest visual quality of the produce as evaluated by a trained panel. Similar results have been obtained with ASC for the reduction of microbial growth in shredded carrots (Ruiz-Cruz et al., 2006a; 2006b; 2007; Gonzalez et al., 2004). The antibacterial activity capacity of ASC is attributed to the low $\mathrm{pH}$ of ASC solutions (2.5) that probably affect the cell's ability to maintain $\mathrm{pH}$ homeostasis, disrupting substrate transport and inhibiting metabolic pathways (Simonne et al., 1997). ASC is currently approved by the FDA to be used in the range 500-1200 $\mathrm{mg} \mathrm{L}^{-1}$ (VLex, 2000). In this concentration range, ASC exhibited strong efficacy over pathogen inactivation on various food products (Gonzalez-Aguilar et al., 2004). However, our results show that even lower ASC concentrations (250 and $500 \mathrm{mg} \mathrm{L}^{-1}$ ) were highly effective at controlling microbial growth, better than other treatments including $\mathrm{OCl}$; ASC was also better at maintaining sensorial quality of fresh-cut jalapeno peppers. Moreover, in preliminary tests, we used ASC at higher concentrations (in the FDA-approved range) on fresh-cut peppers, lettuce, cilantro and spinach and found that it had a negative impact on visual quality, whether or not it was followed by a potable water rinse (data not shown). Similar findings were also reported by Bosilevac et al. (2004) and Roller and Seedhar (2002) who found that red meat products treated with $300 \mathrm{mg} \mathrm{L}^{-1}$ of ASC were superior to those treated with $600 \mathrm{mg} \mathrm{L}^{-1}$. Therefore, our results suggest approval for the use of ASC below $500 \mathrm{mg} \mathrm{L}^{-1}$ should be analyzed since it may better preserve sensory attributes without compromising food safety. FDA approval at these low concentrations is needed before its commercial application.

After ASC, OCl $\left(200 \mathrm{~mL} \mathrm{~L}^{-1}\right)$ treatment was the most effective in maintaining sensory and microbiological quality of fresh-cut jalapeno peppers, followed closely by PA $\left(80 \mathrm{~mL} \mathrm{~L}^{-1}\right)$ treatment. Carvacrol treatment was, on average, as effective as the others in reducing the growth of total aerobic and coliform bacteria; however it showed a strong negative impact on visual sensory attributes of fresh-cut jalapeno peppers and a low effect in reducing growth of yeasts and molds. Carvacrol is a phenolic terpenoid, major component and active ingredient of oregano essential oil and its antimicrobial properties are well documented (Lambert et al., 2001; Zhou et al., 2007), however studies regarding carvacrol's organoleptic impact on fresh-cut produce are limited. Roller and Seedhar (2002) reported that no adverse sensory change was observed on kiwifruit and honeydew melon treated with $1 \mathrm{mM}$ carvacrol. On the contrary and in agreement with the results shown in the present study, Rojas-Grau et al. (2009) observed that, in spite of the low concentration of oregano oil used in the treatment of edible-coated 
fresh-cut apples, consumers detected a residual herbal taste, which diminished overall preference of these samples. It is clear that, carvacrol and/or oregano essential oil have the potential to be used as sanitizers in fresh-cut products, however its effects on sensory quality must be closely evaluated in each specific product.

Green, yellow and red peppers are known to be excellent sources of vitamin $\mathrm{C}$, polyphenols and carotenoids (Chuah et al., 2008; Deepa et al., 2007; Materska and Perucka, 2005; Topuz and Ozdemir, 2007). These phytochemicals show high antioxidant capacity and a diet rich in such compounds has been linked to a decreased risk of developing chronic and degenerative diseases (Gonzalez-Aguilar et al., 2008a). However, as far as we know, there are no studies that show the effect of sanitizers and conservation period on the phytochemical degradation and antioxidant capacity of fresh-cut peppers. Initial concentrations of total phenols and vitamin $\mathrm{C}$ in control fresh-cut jalapeno peppers were similar to those reported by several authors for jalapeno and other sweet and hot peppers (Chuah et al., 2008; Deepa et al., 2007; Howard et al., 1994; Navarro et al., 2006; Oboh et al., 2007; Oboh and Rocha, 2008; Ornelas-Paz et al., 2010). Sanitation process reduced initial total phenols but not vitamin $\mathrm{C}$ concentrations; however, storage reduced vitamin $\mathrm{C}$ (11-42\%) but had no impact on total phenols concentration. These results are in agreement with several authors. Gonzalez-Aguilar et al. (2008b) observed a $20-60 \%$ vitamin $C$ decrease in fresh-cut mangoes stored at $5^{\circ} \mathrm{C}$; Howard and Hernandez-Brenes (1998) reported that ascorbic acid concentration of peppers decreased $17 \%$ when jalapeno peppers were maintained at $4.4^{\circ} \mathrm{C}$ under MAP atmosphere during 15 days; Raffo et al. (2008) observed an 11.6\% reduction on vitamin $\mathrm{C}$ of fresh-cut red sweet peppers treated with $\mathrm{OCl}\left(165 \mathrm{~mL} \mathrm{~L}^{-1}\right)$, kept 9 days at $4^{\circ} \mathrm{C}$. In fact, it is well known that vitamin $\mathrm{C}$ is the most labile phytochemical, which is easily degraded even by mild treatments and during storage (Gonzalez-Aguilar et al., 2010). Nevertheless it should be mentioned that all sanitizers except ASC $500 \mathrm{mg} \mathrm{L}^{-1}$ prevented vitamin C loss, compared to control.

As mentioned before, neither treatment nor storage significantly affected total phenols concentration; however, in Fig. 3a, it is possible to observe that for all treatments there is an increase on total phenols at day 3 and thereafter a slight decrease over time. Even though no enzymatic studies were carried out, this increase on phenolic content could be due to a ripening process that increases PAL activity, which consequently may increase phenolic content of peppers (Simonne et al., 1997).
The antioxidant capacity of green, yellow and red peppers has been determined by several methods, such as 2,2-diphenyl-1-pycrilhydracyl radical, DPPH (Chuah et al., 2008; Materska and Perucka, 2005; Sun et al., 2007), TEAC (Navarro et al., 2006; Pellegrini et al., 2003), $\beta$-carotene bleaching assay (Materska and Perucka, 2005), $\mathrm{Fe}^{2+}$-induced lipid peroxidation assay (Oboh and Rocha, 2008) and ferric reducing/antioxidant power assay, FRAP (Deepa et al., 2007; Marquez et al., 2006). Antioxidant capacity of fruits and vegetables is owed to phytochemicals such as phenolic compounds, vitamins $\mathrm{C}$ and $\mathrm{E}$, carotenoids, among others. In the present study, antioxidant activity was measured by FRAP and DPPH assays. Similar to total phenols, initial FRAP values of antioxidant capacity were reduced in all treatments (except carvacrol) due to a bleaching process. FRAP values were reduced after storage; however this reduction was highest in control samples (43\%). ASC $250 \mathrm{mg} \mathrm{L}^{-1}$ and carvacrol $2.5 \mathrm{mM}$ treated samples showed a significant reduction in FRAP values (35 and 31\% respectively), all other treatments prevented the loss of antioxidant capacity; in fact AP treated samples had higher antioxidant capacity at the end of the storage. When the antioxidant capacity of fresh-cut jalapeno peppers was evaluated with DPPH method, no effect on antioxidant capacity was observed due to sanitation or storage.

The case or carvacrol effect on phytochemicals and antioxidant activity deserves special attention, since it increased initial total phenols and antioxidant capacity and prevented loss of vitamin $\mathrm{C}$ and antioxidant capacity in a high degree; therefore carvacrol treated samples showed the highest final values of phenols, vitamin $\mathrm{C}$ and antioxidant capacity. However, it has been mentioned that carvacrol rapidly reduced acceptability of fresh-cut jalapeno peppers and carvacrol treated samples had the lowest shelf life.

Finally, the correlation studies between antioxidant capacity and concentration of phytochemicals show that phenols are the main contributors to antioxidant capacity in jalapeno peppers, but vitamin $\mathrm{C}$ is also important. These results are in agreement with other authors (Alvarez-Parrilla et al., 2007; Gorinstein et al., 2004).

\section{CONCLUSION}

The following conclusions can be made from the results presented above: (i) ACS at 500 and $250 \mathrm{mg} \mathrm{L}^{-1}$ was the most effective sanitizer in fresh-cut jalapeno peppers, since it reduced microbial growth without significantly affecting sensory quality nor phytochemical content or antioxidant capacity; (ii) 
fresh-cut jalapeno peppers are good sources of phenolic compounds and vitamin $\mathrm{C}$ and sanitizer treatment does not significantly affect the concentration of these phytochemicals, in fact it may prevent their loss during storage; (iii) even though carvacrol treatment was effective in preventing microbiological spoilage and phytochemical loss, it had a strong negative effect on sensory acceptability, further studies should be carried out with carvacrol or oregano essential oil in order to overcome this lack of acceptability and take advantage of its beneficial properties.

\section{ACKNOWLEDGEMENT}

The researchers gratefully acknowledge the financial support from Mexican National Council of Science and Technology (CONACYT) (Project FOMIX-CHIH-2006-C01-57530) and PROMEP (UACJ-CA2005-03).

\section{REFERENCES}

Alvarez-Parrilla, E., L.A. de la Rosa, N.R. Martinez and G.A. Gonzalez-Aguilar, 2007. Total phenols and antioxidant activity of commercial and wild mushrooms from Chihuahua, Mexico. J. Food, 5: 329-334.

http://redalyc.uaemex.mx/redalyc/pdf/724/7245050 1.pdf

Beuchat, L.R., 1998. Surface decontamination of fruits and vegetables eaten raw: A review. World Health Organization.

http://who.int/foodsafety/publications/fs_managem ent/en/surface_decon.pdf

Bosilevac, J.M., S.D. Shackelford, R. Fahle, T. Biela and M. Koohmaraie, 2004. Decreased dosage of acidified sodium chlorite reduces microbial contamination and maintains organoleptic qualities of ground beef products. J. Food Prot., 67: 2248-2254. PMID: 15508637

Chuah, A.M., Y.C. Lee, T. Yamaguchi, H. Takamura and L.J. Yin et al., 2008. Effect of cooking on the antioxidant properties of colored peppers. Food Chem., 111: 20-28. DOI: 10.1016/j.foodchem.2008.03.022

Conesa, A., B.E. Verlinden, F. Artes-Hernandez, B. Nicolai and F. Artes, 2007. Respiration rates of fresh-cut bell Peppers under supertamospheric and low oxygen with or without carbon dioxide. Postharvest Biol. Technol., 45: 81-88. DOI: 10.1016/j.postharvbio.2007.01.011
Deepa, N., C. Kaur, B. George, B. Singh and H.C. Kapoor, 2007. Antioxidant constituents in some sweet pepper (Capsicum annuит L.) genotypes during maturity. LWT Food Sci. Technol., $\quad 40$ : $121-129 . \quad$ DOI: 10.1016/j.lwt.2005.09.016

Gonzalez, R.J., Y. Luo, S. Ruiz-Cruz and J.L. McEvoy, 2004. Efficacy of sanitizers to inactivate Escherichia coli $\mathrm{O} 157: \mathrm{H7}$ on fresh-cut carrots shreds under simulated process water conditions. J. Food Protect., 67: 2375-2380. PMID: 15553615

Gonzalez-Aguilar, G.A., R.M. Robles-Sanchez, M.A. Martinez-Tellez, I. G. Olivas and E. AlvarezParrilla et al., 2008a. Bioactive compounds in fruits: Health benefits and effect of storage conditions. Stewart Postharvest Rev., 48: 1-10. DOI: $10.2212 /$ spr.2008.3.8

Gonzalez-Aguilar, G.A., J. Celis, R.R. Sotelo-Mundo, L.A. de la Rosa and J. Rodrigo-Garcia et al., 2008b. Physiological and biochemical changes of different fresh-cut mango cultivars stored at $5^{\circ} \mathrm{C}$. Int. J. Food Sci. Technol., 43: 91-101. DOI: 10.1111/j.1365-2621.2006.01394.x

Gonzalez-Aguilar, G.A., J.F. Ayala-Zavala, L.A. de la Rosa and E. Alvarez-Parrilla, 2010. Phytochemical Changes in the Postharvest and Minimal Processing of Fresh Fruits and Vegetables. In: Fruit and Vegetable Phytochemicals: Chemistry, Nutritional Value and Stability, De la Rosa, L.A., E. Alvarez-Parrilla and G.A. Gonzalez-Aguilar (Eds.). Wiley-Blackwell, Ames, USA., ISBN: 9780-8138-0320-3, pp: 309-340.

Gonzalez-Aguilar, G.A., J.F. Ayala-Zavala, S. RuizCruz, E. Acedo-Felix and M.E. Diaz-Cinco, 2004. Effect of temperature and modified atmosphere packaging on overall quality of fresh-cut bell peppers. LWT Food Sci. Technol., 37: 817-826. DOI: 10.1016/j.lwt.2004.03.007

Gorinstein, S., A. Caspi, I. Libman, E. Katrich and H.T. Lerner et al., 2004. Fresh Israeli Jaffa sweetie juice consumption improves lipid metabolism and increases antioxidant capacity in hypercholesterolemic patients suffering from coronary artery disease: Studies in vitro and in humans and positive changes in albumin and fibrinogen fractions. J. Agric. Food Chem., 52: 5215-5222. DOI: 10.1021/jf040139j

Heard, G.M., 2002. Microbiology of Fresh-Cut Produce. In: Fresh-Cut Fruits and Vegetables: Science, Technology and Market, Lamikanra, O. (Ed.). CRC Press, Boca Raton, ISBN: 10: 1587160307, pp: 187-248. 
Howard, L.R. and C. Hernandez-Brenes, 1998. Antioxidant content and market quality of jalapeno rings as affected by minimal processing and modified atmosphere packaging. J. Food Qual., 21: $\quad 317-327 . \quad$ DOI: $\quad 10.1111 / \mathrm{j} .1745-$ 4557.1998.tb00525.x

Howard, L.R., R.T. Smith, A.B. Wagner, B. Villalon and E. E. Burns, 1994. Provitamin A and ascorbic acid content of fresh pepper cultivars (Capsicum апnиит) and processed jalapenos. J. Food Sci., 59: $\quad 362-365 . \quad$ DOI: $\quad 10.1111 / \mathrm{j} .1365-$ 2621.1994.tb06967.x

Howard, L.R., S.T. Talcott, C.H. Brenes and B. Villalon, 2000. Changes in phytochemical and antioxidant activity of selected pepper cultivars (Capsicum species) as influenced by maturity. J. Agric. Food Chem., 48: 1713-1720. DOI: 10.1021/jf990916t

Kang, J.S. and D.S. Lee, 1997. Susceptibility of minimally processed green pepper and cucumber to chilling injury by apparent respiration rate Int. J. Food Sci. Technol., 32: 421-426. DOI: 10.1046/j.1365-2621.1997.00129.x

Khkonen, M.P., A.I. Hopia, J.V. Heikki, R. Jussi-Pekka and K. Pihlaja et al., 1999. Antioxidant activity of plant extracts containing phenolic compounds. J. Agric. Food Chem., 47: 3954-3962. DOI: 10.1021/jf9901461

Lambert, R.J., P.N. Skandamis, P.J. Coote and G.J. Nychas, 2001. A study of the minimum inhibitory concentration and mode of action of oregano essential oil, thymol and carvacrol. J. Applied Microbiol., 91: 453-462. DOI: 10.1046/j.1365-2672.2001.01428.x

Marin, A., F. Ferreres, F.A. Tomas-Barberan and M.I. Gil, 2004. Characterization and quantification of antioxidant constituents of sweet pepper (Capsicum annuиm L.). J. Agric. Food Chem., 52: 3861-3869. DOI: 10.1021/jf0497915

Marquez, E., N. Pak, H. Araya and J.L. Rodriguez, 2006. Total antioxidant activity of some vegetables evaluated by FRAP assay. J. Food, 16: 37-41. http://169.158.184.3:8180/jspui/bitstream/ciego100 cia/116/1/Eliosbel.pdf

Materska, M. and I. Perucka, 2005. Antioxidant activity of the main phenolic compounds isolated from hot pepper fruit (Capsicum annuит L.). J. Agric. Food Chem., 53: 1750-1756. DOI: 10.1021/jf035331k

Mercado-Silva, E., V. Rubatzky and M. I. Cantwell, 1998. Variation in chilling susceptibility of jicama roots. ISHS Acta Horticult., 467: 357-362. http://www.actahort.org/books/467/467_40.htm
Navarro, J.M., P. Flores, C. Garrido and V. Martinez, 2006. Changes in the contents of antioxidant compounds in pepper fruits at different ripening stages, as affected by salinity. Food Chem., 96: 66-73. DOI: 10.1016/j.foodchem.2005.01.057

Oboh, G. and J.B.T. Rocha, 2008. Water extractable phytochemicals from Capsicum pubescens (tree pepper) inhibit lipid peroxidation induced by different pro-oxidant agents in brain: In vitro. Eur. Food Res. Technol., 226: 707-713. DOI: 10.1007/s00217-0580-5

Oboh, G., R.L. Puntel and J.B.T. Rocha, 2007. Hot pepper (Capsicum annuum, Tepin and Capsicum chihese, Habanero) prevents $\mathrm{Fe} 2+$-induced lipid peroxidation in brain-in vitro. Food Chem., 102: 178-185. DOI: 10.1016/j.foodchem.2006.05.048

Ornelas-Paz, J.J., J.M. Martinez-Burrola, S. Ruiz-Cruz, V. Ibarra-Junquera and G.I. Olivas et al., 2010. Effect of cooking on the capsaicinoids and phenolics contents of Mexican peppers. Food Chem., 119: 1619-1625. DOI: 10.1016/j.foodchem.2009.09.054

Parish, M.E., L.R. Beuchat, T.V. Suslow, L.J. Harris and E.H. Garrett et al., 2003. Methods to reduce/eliminate pathogens from fresh and freshcut produce. Comprehen. Rev. Food Sci. Food Saft., 2: 161-173.

Pellegrini, N., M. Serafini, B. Colombi, D. Del Rio and S. Salvatore et al., 2003. Total antioxidant capacity of plant foods, beverages and oils consumed in Italy assessed by three different in vitro assays. J. Nutrit., 133: 2812-2819. PMID: 12949370

Raffo, A., I. Baiamonte and F. Paoletti, 2008. Changes in antioxidant and taste-related compounds contend during cold storage of fresh-cut red sweet peppers. Eur. Food Res. Technol., 226: 1167-1174. DOI: 10.1007/s00217-007-0646-4

Rodgers, S.L., J.N. Cash, M. Siddiq and E.T. Ryser, 2004. A comparison of different chemical sanitizers for inactivating Escherichia coli O157:H7 and Listeria monocytogenes in solution and apples, lettuce, strawberries and cantaloupe. J. Food Protect., 67: 721-731. DOI: 10.1016/j.fm.2008.02.003

Rojas-Grau, M.A., S.F.R. and O. Martin-Belloso, 2009. Edible coatings to incorporate active ingredients to freshcut fruits. Rev. Trends Food Sci. Technol., 20: 438-447. DOI: 10.1016/j.tifs.2009.05.002

Roller, S. and P. Seedhar, 2002. Carvacrol and cinnamic acid inhibit microbial growth in fresh-cut melon and kiwifruit at 4 and $8^{\circ} \mathrm{C}$. Lett. Applied Microbiol., 35: 390-394. DOI: 10.1046/j.1472765X.2002.01209.X 
Ruiz-Cruz, S., Y. Luo, R.J. Gonzalez, Y. Tao and G.A. Gonzalez-Aguilar, 2006a. Acidified sodium chlorite as an alternative to chlorine to control microbial growth on shredded carrots while maintaining quality. J. Sci. Food Agric., 86: 1887-1893. DOI: $10.1002 /$ jsfa. 2550

Ruiz-Cruz, S., E. Acedo-Felix, M. Diaz-Cinco, M.A. Islas-Osuna and G.A. Gonzalez-Aguilar, 2006b. ectividad de sanitizantes en la reducción microbiana y calidad de zanahoria fresca corta. Revista Fitotecnia Mexicana, 29: 299-306. http://redalyc.uaemex.mx/src/inicio/ArtPdfRed.jsp? iCve $=61029404$

Ruiz-Cruz, S., E. Acedo-Felix, M. Diaz-Cinco, M. Islas-Osuna and G. A. Gonzalez-Aguilar, 2007. Efficacy of sanitizers in reducing E. coli O157:H7, Salmonella spp. and Listeria monoytogenes populations on fresh-cut carrots. Food Control, 18: 1383-1390. DOI: $10.1002 /$ jsfa. 2550

Sapers, G.M., 2001. Efficacy of washing and sanitizing methods for disinfection of fresh fruit and vegetables products. Food Technol. Biotechnol., 36: 305-311. http://www.ftb.com.hr/39-305.pdf

Sapers, G.M., 2003. Washing and Sanitizing Raw Materials for Minimally Processed Fruit and Vegetable Products. In: Microbial Safety of Minimally Processed Foods, Novak, J.S., G.M. Sapers and V.K. Juneja (Eds.). CRC Press, Boca Raton, London, New York, Washington DC., ISBN: 10: 1587160412, pp: 221-253.

Simonne, A.H., E.H. Simonne, R.R. Eitenmiller, H.A. Mills and N. R. Green, 1997. Ascorbic acid and provitamin A contents in unusually colored bell peppers (Capsicum anпuиm L.). J. Food Comp. Anal., 10: 299-311. DOI: 10.1006/jfca.1997.0544
Sun, T., Z. Xu, C.T. Wu, M. Janes, W. Prinyawiwatkul and H.K. No, 2007. Antioxidant activities of different colored sweet bell peppers (Capsicum annuum L.). J. Food Sci., 72: S98-S102. DOI: 10.1111/j.1750-3841.2006.00245.x

Topuz, A. and F. Ozdemir, 2007. Assessment of carotenoids, capsaicinoids and ascorbic acid composition of some selected pepper cultivars (Capsicum annuum L.) grown in Turkey. J. Food Comp. Anal., 20: 596-602. DOI: 10.1016/j.jfca.2007.03.007

VLex, 2000. 21 CFR173.325-acidified sodium chlorite solutions. VLex. http://cfr.vlex.com/vid/173-325acidified-chlorite-solutions-19706225

Wojdylo, A., J. Oszmiański and R. Czemerys, 2007. Antioxidant activity and phenolic compounds in 32 selected herbs. Food Chem., 105: 940-949. DOI: 10.1016/j.foodchem.2007.04.038

Zhang, H. and J.M. Farber, 1996. The effects of various disinfectants against Listeria monocytogenes on fresh-cut vegetables. Food Microbiol., 13: 311-321. DOI: 10.1006/fmic.1996.0037

Zhou, F., B. Ji, H. Zhang, Y. Zhiwei and J. Li et al., 2007. The antibacterial effect of cinnamaldehyde, thymol, carvacroland their combinations against the foodborne pathogen Salmonella typhimurium. J. Food Safe., 27: 124-133. DOI: 10.1111/j.17454565.2007.00064.x 